\title{
Przekroczenie granicy. Romantyczna podróż i próba pruskości w okresie przedmarcowym - Wácslawa Wladiwoja Tomka wędrówki po pograniczu śląsko-czeskim
}

\author{
DOI: $10.19195 / 2084-4107.12 .8$
}

\section{Wprowadzenie}

Wraz z kształtowaniem się nowoczesnych państw ich polityczne granice od XVIII wieku zyskiwały nowe znaczenie, zarówno w kontekście strukturalnym, jak i dyskursywnym. Otrzymały wreszcie — tam, gdzie jeszcze nie miało to miejsca - formę dokładnej i zazwyczaj także zaznaczonej linii. Ponieważ kraje stopniowo zamykały się jako obszary władzy i przestrzenie w sensie organizacyjnym, a także gospodarczym, rosła potrzeba kontrolowania ruchu ludności, dóbr i idei przez granice, jego politycznej reglamentacji oraz prawnego uregulowania. Tendencja do unifikacji, integracji i wzajemnego odłączania terytoriów państwowych odzwierciedlała się w przebiegających równolegle procesach znoszenia wewnętrznych i budowania zewnętrznych granic. Decyzje co do tego, kto, kiedy i pod jakimi warunkami może przekraczać granicę ${ }^{1}$, stały się jeszcze bardziej, niż to miało miejsce wcześniej, instrumentem rządzenia i organizacji, elementem władzy, który w czasach nowoczesnych uległ ostatecznemu upaństwowieniu.

Kontrowersyjności tematowi granicy (i jej przekraczania) przydawał fakt, że rozwój jej funkcjonalności korelował z rosnącą mobilnością coraz większej liczby ludzi, włączając w to mobilność poza granice państwa. Ponadto procesom tym towarzyszyły przemiany w kolektywnych przynależnościach i tożsamościach, naznaczone przede wszystkim nowoczesnym kształtowaniem się narodów. Skoro naród i państwo oferowały abstrakcyjne, lecz podstawowe formy ludzkiej przynależności, to granica była tą linią i powierzchnią, na której winna się manifestować różnica względem innych lub na której przynajmniej takiej manifestacji różnic oczekiwano i ją zakładano. Przekroczenie granicy stwarzało okazję do uświadomienia sobie inności w rozmaitym względzie - nie tylko w odniesieniu do państwa i jego politycznego systemu, lecz także w kwestii języka, kultury, wyznania, reżimu politycznego, przyzwyczajeń, ale i uwarunkowanych historycznie różnic kulturowych czy strukturalnych, a nawet cech geomorfologicznych. Na początku czasów nowoczesnych (wiek XVIII/XIX) przekroczenie granicy, coraz bardziej będące przedmiotem oczekiwań i refleksji, urosło do sytuacji, w której „sensory kulturowe" przekraczających dosłownie nastawiały się na różnice, szczególnie tam i wtedy, gdy przekroczenie granicy nie stanowiło dla nich codziennej rutyny.

1 Odnośnie do tego kontekstu i na temat Monarchii Habsburskiej zob. A. Komlosy, Grenze und ungleiche regionale Entwicklung: Binnenmarkt und Migration in der Habsburgermonarchie, Wien 2003; por. eadem, Grenzen. Räumliche und soziale Trennlinien im Zeitverlauf, Wien 2018. 
Już same formalności związane z przekraczaniem granicy, czyli kontrole, od końca XVIII wieku dawały asumpt do pierwszych refleksji na temat tego, dokąd się przybywa - i tak na przykład złą sławą cieszyły się w okresie przedmarcowym austriackie kontrole graniczne, zarazem postrzegane jako symptom panowania reżimu politycznego w monarchii habsburskiej, choć wielu podróżnych musiało się dziwić, jak łatwo przeszło tę kontrolę².

W dalszym ciągu rozważań zajmiemy się zbadaniem symptomatycznego indywidualnego przykładu przekroczenia granicy, który miał miejsce w okresie przedmarcowym (to znaczy epoce absolutyzmu w dziesięcioleciach poprzedzajączych Wiosnę Ludów), w latach trzydziestych XIX wieku, jednakowoż w przeciwnym kierunku - z austriackich Czech na pruski Śląsk. Przykład ten dostarcza istotnych dla tego czasu perspektyw, co czyni z niego dobry punkt wyjścia do badania dyskursu dotyczącego różnic na granicy i poza nią:

1. Czesko-śląska, względnie habsbursko-pruska, granica od rekatolizacji Czech (w XVII wieku) stanowiła zarazem granicę wyznaniową i ta jej rola zyskała jeszcze na skomplikowanym charakterze, gdy Śląsk został przyłączony do Prus (w 1742 roku) - z jednej strony na skutek wsparcia udzielonego przez Prusy czeskim potajemnym nie-katolikom, ale i celowego wspierania ich emigracji z Czech na Śląsk przez Fryderyka II; z drugiej strony poprzez początek konkurencji austriacko-pruskiej artykułowanej z obu stron także w kontekście wyznaniowym.

2. Granicę Czech tworzą niemal wyłącznie góry, co dotyczy w szczególności granicy śląsko-czeskiej (pasmo Sudet od Gór Izerskich po Śnieżnik). Skutkiem tego osady po stronie czeskiej i śląskiej były zwykle oddzielone od siebie i tylko w rzadkich przypadkach tworzyły powiązane z sobą przestrzenie osadnicze. W ten sposób po stronie czeskiej „granica” wiązała się z wyobrażeniem o górach, o czym zaświadczają między innymi przedstawienia kartograficzne i opisy kraju już od wczesnych czasów nowożytnych ${ }^{3}$. W czasach nowoczesnych uwarunkowania te prowadziły do wyobrażenia granicy naturalnej ${ }^{4}$.

3. Powstawanie narodów czeskiego i niemieckiego przydały liniom granicznym nowego znaczenia. Po pierwsze, coraz intensywniej zastanawiano się nad granicami dzielącymi obszary większości językowych — jakkolwiek miały one formę co najwyżej stref przejściowych. Po drugie, czeski ruch narodowy wykazywał jednak tendencję do interpretowania Czech w całości jako czeskiej ojczyzny. Sprzyjało to późniejszej internalizacji terenów przygranicznych i gór w czeskim dyskursie dotyczącym przestrzeni. Ponadto w omawianym przypadku chodzi o szczególny region na północy Czech, w którym niemiecko-czeska granica językowa i czeska granica kraju leżały niedaleko od siebie i w której to bliskiej okolicy

${ }^{2}$ M. Power, Hory a moře mezi „,námi”. Vnímáni hranic a prostoru v německé a britské literatuře o Čechách a Irsku v letech 1750-1850, Praha 2015, s. 135-138.

3 Zob. np. P. Stransky, Respublica Bojema, Lugduni Batav 1643, s. 2.

${ }^{4}$ R. Luft, „Alte Grenzen” und Kulturgeographie. Zur historischen Konstanz der Grenzen Böhmens und der Böhmischen Länder, [w:] Grenzen in Ostmitteleuropa im 19. und 20. Jahrhundert. Aktuelle Forschungsprobleme, red. H. Lemberg, Marburg 2000, s. 95-135. 
(na obszarze należącym do Náchodu) zwarty czeski obszar językowy rozciągał się aż do granicy państwowej, a nawet poza nią w tak zwanym czeskim kątku (český koutek) ${ }^{5}$ na ziemi kłodzkiej. Również na północy i zachodzie północno-wschodniej odnogi Czech, a mianowicie na Ziemi Broumovskiej (Broumovsko), o której później będzie mowa, gminy z istotnym lub nawet większościowym udziałem ludności czeskojęzycznej znajdowały się nie dalej niż w odległości kilku godzin pieszej wędrówki od terytorium Prus. Tak ważna dla późnego XIX i XX wieku problematyka inkongruencji granicy państwowej i „granicy” etniczno-językowej stanowiła tu problem w znacznie mniejszym wymiarze niż w innych przygranicznych regionach Czech.

Centralną postacią, która zostanie tu przedstawiona, jest jedna z ważnych osobistości związanych z czeskim rozwojem kulturalnym, naukowym, a po części też politycznym, w XIX wieku. Warto jednak wskazać, że choć zostanie przybliżona w dalszym ciągu niniejszego przyczynku, nie leży ona jako taka na pierwszym planie zainteresowań. Ukazany ma zostać raczej modelowy przypadek młodego człowieka w późnej fazie socjalizacji, praskiego studenta ze średniozamożnej czeskojęzycznej warstwy mieszczańskiej prowincjonalnego miasta, który dopiero w czasie studiów został objęty czeską agitacją narodową. W tej fazie życia przedsiębrał swoje wędrówki w czesko-śląskich górach granicznych, z których przywiózł codzienne notatki, w których zawarł bezpośrednie wrażenia i obserwacje. W dalszej części zostanie dokładniej zbadane, jak góry funkcjonowały jako linia dzieląca różne światy i jakie formy odmienności zostały tu wyrażone oraz jak zostały one „umiejscowione” krajobrazowo; innymi słowy, chodzi tu o kwestię społecznego, kulturowego i przestrzennego rozgraniczenia w historycznie i społecznie jednoznacznie usytuowanym, mikrohistorycznym kontekście.

\section{Wácslaw Wladiwoj Tomek}

Autorem interesujących nas zapisków był Wácslaw Wladiwoj Tomek (1818$1905)^{6}$, ważny przedstawiciel ruchu czeskiego, nauki i polityki w drugiej połowie XIX wieku, jako uczeń Františka Palacký’ego najważniejsza postać w czeskim dziejopisarstwie nowego pokolenia, a zarazem jeden $\mathrm{z}$ aktorów austriackiej supra-

5 Zob. Český koutekv Kladsku. Studie a statè. Kladský sbornik, suplement 5, Hradec Králové 2008.

${ }^{6}$ O życiu i dziele Tomka zob. B. Jiroušek, Historik W.W. Tomek, [w:] W.W. Tomek, historie a politika (1818-1905), red. M. Řezník, Pardubice 2006, s. 15-29; w języku niemieckim por. R.G. Plaschka, Von Palacký bis Pekař. Geschichtswissenschaft und Nationalbewußtsein bei den Tschechen, Graz 1955, zwł. s. 28-35. Jakkolwiek najobszerniejszym przedstawieniem pozostaje do dziś notatka w encyklopedii Ottưv slovník naučný, napisana przez jednego z najmłodszych uczniów Tomka i opublikowana krótko po śmierci Tomka: [V. Novotný] VNov, Tomek Václav Vladivoj, [w:] Ottův slovník naučný, t. 25, Praha 1906, s. 527-547; por. też idem, V.V. Tomek 1818-1918, [w:] V.V. Tomek (1818-1918). Na památku jeho stých narozenin, red. Historický spolek, Praha 1918, s. 7-25. 
nacjonalnej polityki historycznej, szczególnie w latach pięćdziesiątych XIX wieku, kiedy wiedeńskie Ministerstwo Kultury i Nauki (Cultus- und Unterrichtsministerium) zleciło mu stworzenie projektu funkcjonowania seminariów historycznych w Austrii oraz napisanie gimnazjalnych podręczników historii austriackiej, które były w użytku w różnych krajach habsburskich. Działania te przypadły na erę neoabsolutyzmu - czas, gdy rząd wiedeński budował zwartą politykę tożsamości w duchu supranacjonalnego austriackiego patriotyzmu (względnie jednego austriackiego narodu państwowego). Dla Tomka nie stało to w żaden sposób w sprzeczności z jego czesko-narodowym patriotyzmem oraz z jego poglądami na historię jako ważny czynnik czeskiej agitacji narodowej. W tym kontekście należy widzieć jego mianowanie na profesora historii austriackiej na Uniwersytecie w Pradze (1850/1860), a więc powierzenie mu nowo utworzonej katedry. Na praskim uniwersytecie miał wdrażać jedną z centralnych zasad nowej wiedeńskiej polityki nauki — łączenie nauki uniwersyteckiej i badań naukowych w ramach reformy uniwersytetów i oświaty?

Dla ówczesnego ministra kultury i nauki hrabiego Leo von Thun-Hohensteina (1811-1888), czeskiego arystokraty, który w latach czterdziestych XIX wieku popierał zorientowaną autonomistycznie opozycję w czeskim sejmie, Tomek stał się również w innym kontekście ważnym praskim eksponentem — urósł on w czeskiej stolicy i wśród czeskich narodowych patriotów w kraju do roli najważniejszego przedstawiciela tak zwanej partii rządowej gromadzącej się wokół Thuna i próbującej w ramach nowych uwarunkowań politycznych po rewolucji lat 1848/1849 rozwijać dalej dążenia narodowe w dziedzinie kultury, nauki i języka, jednakowoż uwalniając się od liberalnych politycznych „obciążeń” rewolucji i rezygnując z otwarcie politycznego charakteru ruchu. Na tym tle Tomek reprezentował później względnie konserwatywne stanowisko w polityce narodowej, choć po wprowadzeniu konstytucji i parlamentów (1861) ściśle współpracował z liberalnym ugrupowaniem staroczeskim $i$ jako jego poseł wielokrotnie zasiadał w czeskim sejmie oraz w austriackiej Radzie Rzeszy. Jego specyficzna pozycja oraz kontakty umożliwiały mu wówczas pośredniczenie w porozumieniu politycznym pomiędzy czeskimi narodowymi liberałami i patriotycznie nastawioną czeską arystokracją — dzięki wspólnej bazie programowej „czeskiego prawa państwowego” oraz dążeniom do federalizacji Austrii i względnej autonomizacji jej krajów koronnych ${ }^{8}$.

Wprawdzie działalność Tomka z lat pięćdziesiątych XIX stulecia spowodowała, że jego obraz w czeskiej narodowej narracji XX wieku był zdecydowanie ne-

7 Odnośnie do tego kontekstu zob. M. Řezník, The institutionalization of the historical science betwixt identity politics and the new organization of academic studies: Wácslaw Wladiwoj Tomek and the introduction of history seminars in Austria, [w:] Nationalism and Discourses of Objectivity: The Humanities in Central Europe in the Long Nineteenth Century, red. B. Varga, Budapest 2016, s. 250-276.

8 M. Řezník, Český a rakouský politik W.W. Tomek, [w:] W.W. Tomek, historie a politika (1818-1905). Sborník príspěvků královéhradecké konference k 100. výroči úmrtí W.W. Tomka, red. M. Řezník, Pardubice 2006, s. 31-57. 
gatywny i został stopniowo zrelatywizowany dopiero od lat dziewięćdziesiątych, jednakże w drugiej połowie XIX wieku cieszył się mocną reputacją narodowego autorytetu naukowego. Za pośrednictwem swojego bardzo obszernego dzieła historiograficznego Tomek udzielał się przy formowaniu czeskiej pamięci narodowej, choć dzięki swojemu konserwatywnemu i katolickiemu spojrzeniu prezentował w niektórych kwestiach alternatywę do panującej narracji. Mimo wszystko jednak, przykładowo, portret przywódcy armii husyckiej Jana Žižki z Trocno$\mathrm{va}^{9}$, w którym piętnastowieczny dowódca został przedstawiony jako doskonały strateg, dyplomata i polityk, znalazł swoje miejsce w pamięci narodowej. Jego opus magnum stała się natomiast dwunastotomowa - pozytywistyczna w swej koncepcji - Historia miasta Pragi (Dějiny města Prahy) ${ }^{10}$ stanowiąca po części odpowiednik założycielskiego dzieła czeskiej narodowej historiografii, jakim była Historia Czech (Geschichte von Böhmen) tudzież Historia narodu czeskiego w Czechach i na Morawach (Dějiny národu českého v Čechách a v Moravě) ${ }^{11}$ autorstwa mentora Tomka — Františka Palacký'ego.

Jednak w odróżnieniu od Palacký'ego Tomek był historykiem o akademickim zapleczu instytucjonalnym i jako taki udzielał się przy profesjonalizacji nauk historycznych w monarchii habsburskiej w ogólności, a w Czechach w szczególności. Jako jeden z największych autorytetów naukowych, na propozycję Józefa Szujskiego, został zaproszony jako prezes honorowy na obrady pierwszego kongresu historyków polskich w maju 1880 w Krakowie. W Pradze został pierwszym rektorem czeskiego uniwersytetu, po tym jak jego praska alma mater została podzielona w 1882 roku na dwie instytucje narodowe: niemiecką i czeską.

Pod koniec życia Tomka wielkie zainteresowanie budziły przede wszystkim jego dwutomowe, niemal tysiącstronicowe Wspomnienia mego życia ${ }^{12}$. Ponad osiemdziesięcioletni podówczas autor relacjonował swoje przeżycia związane ze sferą społeczną, kulturalną, polityczną i prywatną, poczynając od okresu przedmarcowego, a więc czasów o kluczowym znaczeniu dla czeskiego ruchu narodowego. Tomek rozpoczął spisywanie pamiętników od końca lat sześćdziesiątych XIX wieku, opierając się przy tym nie tylko na własnej pamięci, korespondencji i dokumentach, lecz także na wpisach ze swojego dziennika, który zaczął prowadzić w latach trzydziestych jako student uniwersytetu praskiego i które zachowały się w jego spuściźnie do dziś ${ }^{13}$. Stanowią one również główną podstawę źródłową niniejszych rozważań.

9 W.W. Tomek, Jan Žižka, Praha 1879.

10 W.W. Tomek, Dějepis mésta Prahy, t. 1-12, Praha 1855-1901.

11 Palacký wybrał dla swego dzieła różne tytuły: pierwszy zastosował do wersji niemieckiej, drugi zaś do czeskiej.

12 W.W. Tomek, Paméti z mého žiwota, t. 1-2, Praha 1904-1905.

13 Archiv Národního muzea (Archiwum Muzeum Narodowego - ANM) Praga, Spuścizna V.V. Tomka, karton 19. 


\section{Stawanie się patrioty narodowego}

Droga Tomka do narodowego patriotyzmu w żadnym razie nie była oczywista ani też prosta. Proces tworzenia się narodu czeskiego w okresie młodości Tomka aż do połowy XIX wieku znajdował się w fazie agitacji narodowej — nie był to jeszcze ruch masowy, a idee narodowe reprezentowane były przez małą, jakkolwiek rosnącą grupę. Dla jej działalności z początku nie były zagwarantowane sukcesy i dopiero z późniejszej perspektywy okazała się ona decydująca dla formowania się nowego etniczno-narodowego społeczeństwa. Tak więc bycie narodowym patriotą nie było oczywistą regułą wśród młodych ludzi w latach trzydziestych.

Leżące we wschodnich Czechach rodzinne miasto Tomka - Hradec Králové, historyczne miasto królewskie, a od XVIII wieku również twierdza — z jednej strony było spokojnym prowincjonalnym miastem, z drugiej jednak w drugim dziesięcioleciu XIX wieku rozwinęło się w jedno z najważniejszych centrów agitacji narodowej poza Pragą. Miejscowe gimnazjum, przedstawienia teatralne, wydawnictwo wraz z drukarnią i księgarnią, ale i biskupie seminarium duchowne stworzyły sieć instytucji, w których operowali prominentni, aktywni i wykształceni patrioci narodowi. Działając jak magnes, instytucje te przyciągały dalszych patriotów, promieniując $\mathrm{w}$ ten sposób również poza region.

Tomek pochodził z mówiącej po czesku małomiasteczkowej katolickiej rodziny mistrza szewskiego. Do piętnastego roku życia nie opuszczał miasta, studiował jednak przez sześć lat w gimnazjum, w którym nauczali pedagodzy czynni także w ruchu narodowym i to u nich po części pobierał nauki. Dom jego dzieciństwa i młodości leżał w odległości zaledwie stu metrów od gimnazjum, seminarium duchownego, księgarni i drukarni z wydawnictwem. Tomek jednak zupełnie nie przejmował się agitacją narodową i raczej jej nie dostrzegał. W jego rodzinnym domu najwyraźniej nie mówiło się o niej. Nie czytał czeskich autorów (z których dwóch było jego profesorami gimnazjalnymi), lecz Waltera Scotta w niemieckim tłumaczeniu oraz klasykę literatury niemieckiej. W swoich wspomnieniach pisał: „Słowo »patriota« słyszałem wprawdzie kilka razy, jednak zawsze towarzyszyło mu trochę kpiny. Pojąłem, że tak nazywają siebie ludzie, którzy chętnie mówią po czesku i zwracają się do siebie przez "wy«"14.

Gwałtowna zmiana nastąpiła po tym, gdy w 1833 roku Tomek przeprowadził się do Pragi i podjął tam studia na wydziale filozoficznym, a potem prawniczym. Pod bezpośrednim wpływem swoich patriotycznych kolegów o poglądach narodowych zaczął się interesować narodową kulturą i przeszłością. Mimo początkowego sceptycyzmu dał się wkrótce porwać ideom narodowym i zaangażował się aktywnie w agitację. Ćwiczył się w języku czeskim i wkrótce stał się zagorzałym orędownikiem czeskojęzycznego patriotyzmu. Zarówno w ten sposób, jak i po-

14 „Slowo »wlastenec« jsem předce několikkrát slyšel, ale wždy s nějakým úsměškem. Porozuměl jsem, že se tak nazýwají lidé, kteří mluwí rádi česky a wykají »si«" — W.W. Tomek, Paméti..., t. 1, s. 49. 
przez swoje zainteresowania historyczne, dzięki którym szybko zaczął publikować w czeskiej prasie, zwrócił na siebie uwagę publiczności patriotycznej. Wkrótce polecono go jako domowego nauczyciela rodzinie Františka Palacký'ego i tak z końcem lat trzydziestych XIX wieku rozpoczęła się jego kariera przyszłego historyka i aktywisty narodowego. Nowe perspektywy odciągnęły Tomka jednak od rozpoczęcia jako prawnik kariery urzędniczej i objęcia oferowanej mu posady we Lwowie.

Wyjazd na studia do Pragi oraz miesiące i lata, które nastąpiły bezpośrednio po nim, oznaczały jednak w życiu podówczas piętnasto-, szesnasto- i siedemnastolatka przełom osobisty i to pod wieloma względami. Zostanie on tu wspomniany tylko na tyle, na ile jest istotny dla tematu tego artykułu.

Po pierwsze, Tomek do tej pory spędzał życie wyłącznie w swoim mieście rodzinnym i jego najbliższej okolicy, a w każdym razie nie opuszczał miasta na dłużej niż pół dnia. Miało to wpływ na jego horyzonty poznawcze i — jak się miało niebawem okazać - uczyniło z Hradca Králové wzorzec absolutny, który służył mu do oceny innych miejscowości i krajobrazów. Przeniesienie się do Pragi było więc radykalną zmianą — teraz oddalony ponad sto kilometrów od swego rodzinnego miasta spędzał większość czasu w czeskiej metropolii, a do domu wracał tylko na wakacje. Praga pozostała dla niego przez trwającą siedemdziesiąt lat „resztę” życia miejscem działania i zamieszkania.

Zainteresowanie ruchem narodowym było oczywistym skutkiem wejścia w nowe środowisko społeczne i kulturowe. Jednocześnie stanowiło ono jedno z radykalnych i decydujących doświadczeń w kluczowej fazie socjalizacji młodego mężczyzny i kształtowaniu się jego osobistej, indywidualnej tożsamości wraz z jej kolektywnymi odniesieniami.

Po drugie, poszerzenie horyzontów związane z przeniesieniem się do Pragi miało dalsze skutki. Tomek regularnie przebywał w towarzystwie studentów z różnych części Czech i zaczął się interesować nie tylko Pragą, lecz także regionami, z których pochodzili jego koledzy i przyjaciele. Nowe horyzonty w sensie geograficznym z jednej strony, a zainteresowanie tym, co narodowe, czeskie z drugiej - kształtowały nowe wyobrażenie ojczyzny, które rozsadzało lokalne ramy jego małej ojczyzny. Proces ten przyśpieszyła jego fascynacja wędrówkami przez Czechy podczas wakacyjnych pieszych podróży do Hradca Králové, podczas wycieczek w dalszą okolicę Pragi oraz odwiedzin u południowoczeskich przyjaciół. Piesze wędrówki szybko stały się namiętnością, która towarzyszyła mu przez całe życie, szczególnie w czasie wakacji, także w późniejszym czasie, kiedy był już profesorem.

Po trzecie, procesom kształtowania się tożsamości i socjalizacji towarzyszyły inne gwałtowne wydarzenia mające wpływ na formowanie się osobowości Tomka. Niedługo po jego przeprowadzce do Pragi zmarł w Hradcu Králové jego ojciec, a tym samym głowa rodziny. Mentorem Tomka stał się teraz jego starszy brat Josef, także studiujący w Pradze i mieszkający razem z nim. Latem 1835 roku i tu jednak doszło do rozłamu — pierwotnie było bowiem postanowione, że Tomek 
po dwuletnim kursie filozofii będzie studiował medycynę, jednak pod wpływem swoich zainteresowań kulturalnych i historycznych zrezygnował z tych planów, decydując się wbrew woli brata na studia prawnicze. Stało się to kosztem posłuszeństwa i ze zlekceważeniem autorytetu Josefa, a tym samym spowodowało otwarty konflikt w rodzinie, który eskalował w czasie wakacji w Hradcu Králové w 1835 roku. Tomek przeżył w ten sposób bolesną emancypację spod opieki brata. W powstałej w ten sposób dusznej atmosferze w domu, grożącej popsuciem wakacji, ucieszył się z oferty przejęcia w okresie wakacyjnym obowiązków nauczyciela i wychowawcy w domu Josefa Dáni, zarządcy benedyktyńskiego dominium Police nad Metują (Police nad Metují) należącego do sąsiedniego klasztoru w Broumowie (Broumov). Pobyt ten stał się w kolejnych latach tradycją, Tomek zżył się z rodziną i lokalną społecznością, a także zachwycił się miejscowością i otaczającym ją krajobrazem. Spędzał potem każde lato w Policy, oddając się swojej pasji do wędrówek, gdy tylko miał ku temu okazję. To właśnie tutaj, w rodzinie Dáni, poznał jako ośmioletnią dziewczynkę Ludmilę („Liduszkę”), młodszą siostrę swego wychowanka. Latem 1847 roku została jego żoną; jej śmierć dwadzieścia jeden lat później stała się dla Tomka powodem rozpoczęcia spisywania swoich wspomnień, o których była już mowa. Police jednak nie tylko dlatego stały się jego drugą ojczyzną — tu spędzał wakacje i dużo więcej czasu niż w swym rodzinnym mieście, które teraz odwiedzał zazwyczaj tylko po drodze z Pragi do Policy.

W „brzemiennym” roku 1835 dziewiętnastoletni podówczas Tomek zaczął prowadzić dziennik. To także przemawia za tym, że dużo się w jego życiu i jego umyśle działo, że zaczął zajmować się swoją osobą i zastanawiać nad sobą. Pisany z początku po niemiecku dziennik, w którym Tomek nagle i bez jakiegokolwiek komentarza przeszedł na język czeski, informuje nas bez pośrednictwa późniejszych wspomnień o jego pierwszych przeżyciach z Ziemi Broumowskiej oraz $\mathrm{z}$ nieodległych rejonów Śląska.

\section{Wędrówki przez przygraniczne góry}

Ma to związek z górami dlatego, że Tomek poznawał i postrzegał krajobraz wokół Policy jednoznacznie jako krainę górską. Wcześniej znał góry tylko z horyzontu Hradca Králové, z którego punktów widokowych można było oglądać panoramę odległych o około czterdzieści kilometrów Gór Orlickich na wschodzie i leżących jeszcze dalej Karkonoszy na północy. Poza tym Hradec Králové leży na równinie ciągnącej się bez większych wzniesień aż do Pragi. $Z$ tego względu nierówności bezpośredniej okolicy Pragi były dla niego nowym przeżyciem, a piesza wędrówka na południe Czech poprzez pofalowany, lecz w żadnym razie nie górski, krajobraz - szczególnym wyzwaniem ${ }^{15}$, choć poza tym pokonanie stu kilometrów pomiędzy Pragą a Hradcem Králové nie przysparzało mu żadnych problemów.

15 ANM, Spuścizna V.V. Tomka, karton 19, wpis z maja 1837. 
Gdy latem 1835 roku pozostawił za sobą Náchod i udał się dalej na północ, był pod szczególnym wrażeniem krajobrazu. Już tu widział siebie w górach, jakich dotąd nigdy nie zobaczył. Romantyczną fascynację krajobrazem odzwierciedlają wpisy w dzienniku pochodzące $\mathrm{z}$ tamtych czasów. To opisy przyrody, krajobrazu zapełniają, prócz opisów codziennego życia, strony jego pamiętnika; uwagę zwraca zaś brak jakichkolwiek odniesień do przejść językowych, choć Tomek znajdował się już na obszarze dwujęzycznym i wszystkich nazw na Ziemi Broumowskiej używał wyłącznie po niemiecku — w odróżnieniu od późniejszych wspomnień ${ }^{16}$. Wydaje się, że czeskie warianty nazw nie były mu na początku znane pomimo narodowo-patriotycznych przekonań i kontaktów z czeskojęzycznymi mieszkańcami Policy.

Wycieczki w skalistą i górzystą okolicę należały już latem 1835 roku, a i w późniejszych latach do najmilszych przeżyć z tego pobytu. Opisy przyrody pochodzące $z$ tamtych czasów są całkowicie zdominowane przez romantyczną imaginację - Tomek nie tylko ukazuje swoją fascynację odległymi widokami, lecz opisuje przede wszystkim kontrasty pomiędzy światłem i cieniem, a także wysokością i głębokością, barwność przyrody, malowniczość gór i formacji skalnych, własne uczucia i wrażenia. Tak jak w sierpniu 1835 roku w czasie swej pierwszej wycieczki do kaplicy Hvězda w Broumowskich Ścianach — do dziś obowiązkowego punktu programu dla wędrujących po tych okolicach:

a tu nagle przy kaplicy napotyka się miejsce, które zaskakuje bardzo swoją naturalnością. Jest to skała nad straszliwą porośniętą lasem przepaścią, z widokiem na długą Kotlinę Broumowską [...]. W jej środku stoi Broumow, a wokół niego te długie wsie, w których żyje najmocniejsza ludność Europy; horyzont zaś ograniczają stojące w długim, pokrytym lasem rzędzie wysokie wzgórza na granicy śląskiej; wśród nich na prawo widać wieżyczkę kościoła w Šonovie, gdzie Jan stacjonował przed dwoma laty ${ }^{17}$. Wokół widać pełno skał, na które niepodobna się wspiąć, głębokie doliny i las. Wszystko to razem pozwala na wspaniałe spojrzenie na przyrodę, przy którym człowiek sam sobie zdaje się być całkiem mały ${ }^{18}$.

16 W.W. Tomek, Paměti..., t. 1, s. 119-126.

${ }^{17}$ Chodzi o barokowy kościół pw. św. Małgorzaty w Šonovie (niem. Schönau). Brat Tomka Jan służył tu jako urzędnik austriackiej administracji celnej, zanim został na resztę swego życia przeniesiony do Galicji, gdzie później odszedł ze służby państwowej i pracował jako zarządca dóbr leśnych.

18, ,A] tut' se přigde u gakési kaplički na gednau na mjsto, které swau krásau přirozenau welmi překwapj. Gest to skála nad hroznau propastj, lesem porostlau, a poskjtugjci wýhledku nad roztáhlau planinu (gak se zdá, neb dole pak gsau widět nerownosti) Braunowskau. U prostřed ni stogj Braunau, a okolo onné dlauhé wsy, w nichz neysylněgšj objwaletswo w Europě se nachazj; a obzor obmezugj weliké wrchi na mezých Slezských w dlauhém řadě, lesem př́krité; w tomto gest w prawo widět wěžku kostela Schönauského, kde Jan před dwauma leti ležel. Okolo sebe ge widět samych skal, na něž se ani wylezti nemuže, hlubokých dolu a les. Wšecko to dohromadi gest weliký pohled na přirodu, při němž se člowěk do cela malým být cýtj. I když se zpět gde gest pohled 
O ile Tomek przy pierwszej sposobności komentuje śląską granicę i ujmuje ją przynajmniej ,wizualnie”, to już dziewięć dni później nadarza mu się pierwsza możliwość doświadczenia granicy oraz krótkiego pobytu w sąsiedzkim kraju wybrał się mianowicie na pierwszą ze swoich niezliczonych, powtarzających się co roku wycieczek na Szczeliniec Wielki (919 m n.p.m.) — najwyższy szczyt Gór Stołowych, znajdujący się w zachodniej części ziemi kłodzkiej, zaledwie około dwa kilometry od granicy czeskiej, który i dziś fascynuje swymi piaskowcowymi formacjami, a już wtedy był magnesem dla turystów. Lecz to, co z perspektywy Broumowskich Ścian było Śląskiem, jest w opisie tej wędrówki w jednoznaczny sposób również Prusami - do tego opisowi temu towarzyszą negatywne oceny przypominające niektóre modne stereotypy dotyczące pruskości: w Karłowie „piliśmy w pewnej gospodzie pomyje pod nazwą piwa”; za „chleb z masłem gospodarz kazał sobie bardzo dobrze zapłacić, jak to ma miejsce wszędzie na Śląsku". Nawet widok sięgający aż po Śnieżkę na zachodzie i po Kłodzko na wschodzie wprawdzie zrobił na nim wrażenie, gdyż „dziwnie oddziałowuje na człowieka”, lecz „,przyroda jest tu zniszczona, gdyż aż na sam szczyt przez skały i lasy prowadzą stopnie, tak że nie wolno na niego wchodzić z żadnej innej strony"19.

Ciąg dalszy tego pierwszego zetknięcia się z granicą, Prusami i Śląskiem miał miejsce o wiele intensywniej trzy lata później. Tomek wybrał się wtedy wraz ze swoim uczniem Aloisem Dáňą na wspólną wędrówkę po pograniczu śląskim oraz po górach leżących na granicy austriacko-pruskiej. Miała ona prowadzić zaraz nad Broumowem na teren Śląska i być kontynuowana przez Wałbrzych aż w Karkonosze. Została jednak przedwcześnie przerwana - ponieważ Alois nabawił się problemów ze stopą, wrócili z Wałbrzycha przez Chełmsko Śląskie do Czech. Poznali jednak w ciągu kilku dni formy krajobrazu środkowych Sudetów: Góry Jastrzębie, Góry Suche, Góry Sowie i Góry Wałbrzyskie, a także przewędrowali tereny na wschód od Karkonoszy, zwiedzając Głuszycę, Jedlinę-Zdrój, Książ, Szczawno-Zdrój i klasztor w Krzeszowie.

Droga przez granicę kraju i państwa prowadziła Tomka i jego wychowanka z Broumowa przez Janovičky do Głuszycy będącej pierwszą śląską miejscowością na wybranej trasie. Przekroczenie granicy, przy którym Tomek zwrócił uwagę na tablice z godłami państwa austriackiego i pruskiego jako na dokładne oznaczenie linii granicznej, dało asumpt do zauważenia i skomentowania pierwszych różnic. Odmienność zauważał przy tym nie w obrębie krajobrazu, lecz w kontekście kulturalnym i społecznym w szerokim rozumieniu — były to z jednej strony różnice wyznaniowe, na które od razu skierował uwagę, z drugiej jednak wypadające na

krásný, zwláště tu Wostacz přicházj o mnoho wětšj a mocněgšj, i Kluček má z této strani pěkněgšji pohled, než od Polic" - ANM, Spuścizna V.V. Tomka, karton 19, wpis z 21 sierpnia 1835 roku.

19 „[W] hospodě gsme pili patoky pod gmenem piwa”; „Přiroda jest tu zkažená, nebot’ wedou až na horu přes les a skaly schodi; proto se nesmj ani ginau stranau tam wylézt”; „Ty rozličné wjsky, lesjki, wrchi a wšecko co na gednau užjt muže, aučinkuge podiwně na člowěka”; ,[...] což sy p. Hospodský dobře nechal zaplatit, gak to w Slezsku wšudy uměgj" - ANM, Spuścizna V.V. Tomka, karton 19, wpis z 30 sierpnia 1835 roku. 
korzyść Śląska rozbieżności w poziomie życia. Tak jak współczesnych mu, którzy przechodzili przez Rudawy (Krušné hory, Erzgebirge) z Saksonii do $\mathrm{Czech}^{20}$, tak i jego przekroczenie grzbietu górskiego i wkroczenie do pierwszej miejscowości w sąsiednim kraju sprowokowało do skoncentrowania się na różnicach pomiędzy obydwoma krajami, przy czym ta i tamta strona politycznej i historycznej granicy zostały sobie przeciwstawione jako dwa byty.

Już więc w Głuszycy Tomek podziwiał

wielkie domy, lub przynajmniej do pewnego stopnia porządnie zbudowane, a i większe chałupy. Obok ładnych dróg jest to druga rzecz, po której odróżnić można śląski krajobraz od czeskich terenów przygranicznych. W ogóle w Czechach panuje przekonanie, że należy budować tak bez smaku jak i biednie; tu natomiast wszystko jest zdobione. Bolało mnie to i niemal zazdrościłem Ślązakom, jednak w końcu przestałem im tego żałować ${ }^{21}$.

To wskazanie na różnice „cywilizacyjne”, kulturowe powtarza się jak w lustrzanym odbiciu w opisie drogi powrotnej, kiedy między Chełmskiem Śląskim i Adrspachem rozpoznali linię graniczną ,po obu orłach, a niebawem także po złych drogach"22. Długo utrzymujący się stereotyp o gorszych drogach w Czechach, odróżniających się od dróg w Prusach czy Niemczech, zaznacza się już tutaj. Tomek wykazuje się jednak zupełnie przednarodowym, raczej punktowym niż linearnym, postrzeganiem granicy, które nie jest szczególnie nacechowane emocjonalnie, co staje się tak charakterystyczne dla późniejszych kontekstów narodowych. Dla wcześniejszego postrzegania typowe jest koncentrowanie się recepcji na symbolach władzy państwowej, takich jak kamienie graniczne i godła ${ }^{23}$.

Jednak w Głuszycy to obecność konfesji augsburskiej przede wszystkim przyciągnęła uwagę Tomka. Ten wychowany surowo po katolicku i tak odczuwający prawnik, który już krótko po swoich studiach nad Heglem miał przełamać osobisty kryzys wiary ${ }^{24}$, pozostawał wprawdzie w ścisłym kontakcie z niekatolickimi i liberalnymi autorytetami ruchu czeskiego w Pradze (Pavel Josef Šafař́́k i František Palacký), jednak jeszcze nigdy nie zetknął się ze wspólnotą, która byłaby w większości innego wyznania i w której Kościół ewangelicki zajmowałby pozycję

${ }^{20}$ M. Power, op. cit., s. 129-150.

21 „Weliké domy, neb zas aspoň gaksi slušně stawené, i neywětší chalupy. Mimo krásných cest, jest toto druhá wěc, která slezskau, od české pomeznj kraginy rozeznati dá. W Čechách se wůbec tak newkusně, gak chudě musit stawiti myslj; tuto wše ozdobně. Bylo mi toho ljto, a záwiděl sem tak skoro Slezanům, pak sem gim toho zas přál" — ANM, Spuścizna V.V. Tomka, karton 19, wpis z sierpnia 1838 roku.

22 „[P]odlé dwau orlů, gakož i brzy podle špatných cest” — ibidem.

23 Por. B. Struck, Nich West - nicht Ost. Frankreich und Polen in der Wahrnehmung deutscher Reisender zwischen 1750 und 1850, Göttingen 2006, s. 200-220.

${ }^{24}$ W.W. Tomek, Paméti..., t. 1, s. 138. 
wyznania państwowego. Dlatego też wizyta w kościele luterańskim w Głuszycy ${ }^{25}$ stała się jego pierwszym naprawdę wielkim przeżyciem po śląskiej stronie granicznych gór. Godne uwagi jest przy tym również jego przejście od przemyśleń natury konfesyjnej do tematu polityki oraz pruskiego i regionalnego kalendarza pamięci. Tomek dał tu jednocześnie wyraz swoim ówczesnym liberalnym przekonaniom oraz aktualnym politycznym sympatiom, które z pewnością nie były propruskie:

Obejrzeliśmy sobie jeszcze protestancki dom modlitwy. Ma on ładne wejście, jak w greckiej świątyni, z kolumnami; nad nią wznosi się wysoka wieża, na której jak to wszędzie u protestantów nie toleruje się krzyży; chciałbym wiedzieć czemu. Jednak za wieżą wygląda to jak duża chłopska chałupa, która wyglądałaby lepiej, gdyby nie tak piękne wejście i wieża. Wnętrze (nie wiem, czy jest tak wszędzie u protestantów) jest zbudowane na kształt teatru. Na dole miejsca do siedzenia, na górze miejsca do siedzenia, w dwóch galeriach jedna nad drugą; wolnego miejsca tylko tyle, aby dostać się do ławek i do ambony, też trochę przed ołtarzem. Na prawo od ołtarza wisiał obraz Marcina Lutra, który wygląda zupełnie inaczej niż Mag. Jan Hus; po lewej stronie obraz obecnego króla pruskiego jako zwierzchnika kościoła w swoich państwach, nieopodal [obrazy — M.̌̌.] kilku innych królów (także marszałka Blüchera), całkiem z tyłu jeszcze kilku pastorów tej parafii. Nad drzwiami zaś są wypisane na tablicy nazwiska mieszkańców Głuszycy, którzy polegli w latach [18]13 i [18]14. To również mi się nie podobało, gdyż musiałem pomyśleć o artykule 13 Kongresu wiedeńskiego ${ }^{26}$ i o konstytucji stanowej w Prusach. Odebrałem to jak kpinę z tych ludzi. Bardziej podobałaby mi się tablica z nazwiskami poległych w Paryżu w czasie Rewolucji Lipcowej i to obok pomnika Napoleona ${ }^{27}$.

25 Dzisiejszy katolicki kościół parafialny pw. Marii Królowej został wybudowany w 1809 roku jako ewangelicki dom modlitwy i urządzony w formie opisanej przez Tomka.

26 Nie jest jasne, co dokładnie Tomek miał na myśli; przypuszczalnie pomylił się w numeracji artykułów: art. 13 wiedeńskich aktów końcowych regulował wyjątki od zniesienia konfiskaty dóbr i zarekwirowań we wcześniejszym Księstwie Warszawskim, nie miał więc dostrzegalnego związku z komentarzami Tomka.

27 „Geště gsme se na protestantskau modlitebnu podjwali. Ta má krásný wchod, gako do řeckého chrámu, se slaupy; nad njm gest wysoká wěž, na njž se gako wšudy ginde u protestantů, křjže netrpj; wědělbych rád proč. Ale za wěží a za wchodem stogj gako weliká chalupa, kterážby lepši wypadala, kdyby tak krásného wchodu a wysoké wěže u nj nebylo. Wnitřek gest (newjm, zdali to wšady u protestantů obyčeg) stawen asi na způsob diwadla. Dole wůkol sedadla, nahoře wůkol sedadla w dwau gallerijch, které nad sebau stogj; mjsta jen tolik co by se do sedadel a na kazatedlnu wstaupilo, a něco před oltářem ponecháno. Od oltáře w prawo wisel na prwnj gallerii obraz Martina Luthera, kerý docela na opak, než M. Jana Husi wyhljžj; na lewé straně nyněgšjho krále, co hlawy cjrkwe we Státech swých, několika giných králů opodal toho (maršála Blüchra také), neyzáz několika pastýřů obce té. Ale nade dweřma stála gména giersdorfských, w létech 13. a čtrnáctém padlých, na tabuljch napsaná. To se mi také neljbilo, protože sem si na 13. článek wjdenského congressu a stawowské zřjzenj w Prusjch wzpomenauti musil. Tož mi bylo, gakoby se dobrým těm posmjwat 
Jak widzimy, nawet empory kościelne były dla Tomka nigdy wcześniej niewidzianym artefaktem, który przypominał mu wyłącznie widownię teatralną. Każda odmienność niemal automatycznie prowadziła u niego w kontekście konfesyjnym do zdystansowanej aż po negatywną ocenę, lecz dopiero polityka historyczna władz pruskich, manifestująca się w przestrzeni kościoła, skłoniła młodego praskiego prawnika do ironicznych komentarzy. Także później Tomka zajmowały różnice i napięcia wyznaniowe - podczas lektury licznych numerów „Breslauer Zeitung” w czasie pobytu w Kamiennej Górze „rzuciło mi się w oczy, że mówiło się tu o katolicyzmie o wiele bardziej wrogo niż u nas znalazłoby się o protestantyzmie". Kościelny w przyklasztornym kościele w Krzeszowie opowiedział mu jeszcze ,z wielkim smutkiem o upadku swego domu bożego pod wrogimi pruskimi rządami" 28 .

O ile pierwsze wrażenia zawężone były do kwestii politycznych, religijnych i kulturalnych, a przyroda i krajobraz z początku pozostawały odsunięte na bok, o tyle w kolejnych dniach wędrówki w kierunku północnozachodnim nastąpiła zmiana perspektywy. Teraz Tomek zaczął interesować się szczegółami budownictwa, specyfiką krajobrazu, które obserwował z różnych punktów widokowych, a także wrażeniami, które w nim wywoływały i pozostawiały po sobie takie obserwacje. Spośród odwiedzanych miejscowości szczególnie Jedlinie-Zdrój poświęcił krótki, lecz pełen zachwytu opis. Co do krajobrazów, to przede wszystkim te z okolic Wałbrzycha i Szczawna wywołały w nim głęboko romantyczne wrażenia, podobne do tych z góry Hvězda w Bromowskich Ścianach. Nawet przy zamku i sąsiadującej z nim starej ruinie w Książu, którego zwiedzanie stanowiło najważniejszy punkt w programie wędrówki, szerzej komentował rozległy krajobraz i głębokie przepaście wokół zamku niż tutejsze dziedzictwo historyczno-kulturalne. ,Jest tu tak daleki, daleki widok wokół, tak wiele różnorodnych przedmiotów, że oko z początku zagubione nie wie, gdzie ma spojrzeć" 29 . Jednak wyglądając z okna zamku w Książu, nie zapomniał swego wzorca, który stosował zawsze i nosił z sobą — porównał go do widoku z renesansowej Białej Wieży w Hradcu Králové, górującej nad jego rodzinnym miastem, stojącej jednakowoż w środku miasta, a także z widokiem z ruiny średniowiecznego zamku Kunětická Hora stojącego na górze w środku równiny nad Łabą we wschodnich Czechach, która była pierwszą w ogóle ruiną zwiedzaną przez Tomka ${ }^{30}$.

geště chtěli. Toby se mi tabule w čerwencowé rewolucj padlých w Pařjži, nadherná a podlé sochy Napoleonowy, lépe ljbila" - ANM, Spuścizna V.V. Tomka, karton 19, wpis z sierpnia 1838 roku.

28 W.W. Tomek, Paměti..., t. 1, s. 125.

29 „Tut' gest široký, široký obzor, tolika rozmanitých předmětů, že oko neyprw pomateno, ani kamby se obrátit neyprw mělo, newj” - ANM, Spuścizna V.V. Tomka, karton 19, fol. 91 (numeracja rozpoczyna się dopiero w środku pamiętnika).

30 Ibidem. O zwiedzaniu Kunětickiej góry zob. W.W. Tomek, Paměti..., t. 1, s. 47-48, 54-55. 


\section{Płaszczyzny porównania}

Hradec Králové jako wzorzec oraz porównanie wiejskiego budownictwa i jakości dróg to jednakowoż jedyne przypadki, w których Tomek wyraźnie powołuje się w czasie swoich wędrówek po górach pogranicza czesko-śląskiego na płaszczyznę wziętą z ojczyzny. Pozostałe osądy obywają się bez tego bezpośredniego odniesienia. Pośrednio jest ono jednak ciągle obecne we wszystkich jego opiniach, odgrywając w nich nawet decydującą rolę poprzez swą domniemaną oczywistość i wywoływane automatyzmy myślowe. Niezwykłość, a nawet niezrozumiałość wystroju protestanckiego kościoła, za którą domyślał się przyczyn dogmatycznych, ale i pruskiej, wciskającej się do wnętrza kościoła polityki pamięci, wynikały dla niego naturalnie z domniemanej normalności, w której żył. Dotyczyło to w końcu również codziennych kwestii, takich jak prowadzenie dróg turystycznych, ceny i jakość piwa pod Szczelińcem. Od czasu do czasu jednak, co widać szczególnie w Głuszycy, doświadczenie inności skłaniało młodego człowieka, jakim był Tomek, do ogólnych przemyśleń natury politycznej i społecznej i z całą pewnością miało też wpływ na postrzeganie swojskiego ojczystego otoczenia i jego realiów. Wszystko to było jeszcze wzmacniane — przypuszczalnie za sprawą jego wieku — przez ,romantyczną podróż” (w prawdziwym i przenośnym znaczeniu), przez scenerię przyrody i krajobraz, które najwyraźniej wprawiały go w stan romantycznego zachwytu.

\section{Wnioski}

Była to też pierwsza płaszczyzna transgresji, których dokonał Tomek w czasie swoich wędrówek przez góry pogranicza. Obok „romantycznej podróży”, oznaczającej również przełamanie jego dotychczasowych horyzontów, było to przekroczenie granicy kraju w ścisłym tego słowa znaczeniu — doświadczenie przekroczenia granicy jako zupełnie nowa, podlegająca refleksji praktyka kulturowa XIX wie$\mathrm{ku}^{31}$. Przejście na obszar różniący się pod względem politycznym, kulturowym, religijnym, a po części także społecznym i językowym, przejęło - jako trzecia płaszczyzna - poprzez swą silną prezencję poznawczą, rolę katalizatora dla innych płaszczyzn transgresji.

Jeśli streścimy raz jeszcze płaszczyzny percepcji pojawiające się w zapiskach Tomka, zaobserwujemy przede wszystkim, z jednej strony, romantyczną fascynację młodego człowieka wywołaną scenerią krajobrazu i jednocześnie z powrotem w nią przenoszoną. $Z$ drugiej zaś strony wędrówka pobudziła istniejące od zawsze kulturalne zainteresowania wędrowca. Kierowały się one przede wszystkim na

31 Por. L. Řezníková, Hranice jako sociální instituce a geografická kategorie v raně novověké imaginaci prostoru. K současnému výzkumu hranic v raném novověku, „Studia Comeniana et Historica” 47, 2017, s. 115-131. 
płaszczyznę wyznaniową, przy czym na pierwszym planie stały nie religia, wiara, dogmatyka, lecz raczej związane z wiarą ewangelicką artefakty kulturowe. Samą wyznaniowością Tomek interesował się raczej mniej (nazywał też religię po prostu „protestancką” bez dalszego różnicowania), a w każdym razie mniej niż wyglądem kościoła luterańskiego na zewnątrz i wewnątrz. Tomek odczuwał ponadto odmienność między Czechami a Śląskiem również w obszarze poziomu życia, budownictwa, jakości ,infrastruktury”, przy czym ta płaszczyzna porównania nie jest raczej bezpośrednio formułowana, a w dodatku ani oba kraje, ani obie monarchie nie są sobie przeciwstawiane jako porównywane podmioty. Nie przeszkadza to Tomkowi wyrażać się w sposób ironiczny o pruskiej polityce wyznaniowej - jednak ta krytyka podówczas młodego liberała najwyraźniej mniej dotyczy samych Prus, a bardziej „Reakcji”. Jego zainteresowania kulturą i krajobrazem uwidaczniają się szczególnie w czasie zwiedzania Książa, gdzie oba te elementy (malowniczy relikt historii i postrzeganie krajobrazu) mogły połączyć się we wprost romantycznej, a przynajmniej romantyzującej harmonii.

\section{Epilog}

Z punktu widzenia osobistego rozwoju Tomka wędrówka ta miała znaczenie wynikające $\mathrm{z}$ kontekstu związanego $\mathrm{z}$ fazą psychiczną, mentalną i duchową, a także z sytuacją, w której się właśnie znajdował. $Z$ dalszej perspektywy istotna rola tejże wędrówki wiązała się również z faktem, że był to nie tylko pierwszy przypadek, w którym Tomek opuścił Czechy, względnie monarchię habsburską, ale i na długi czas ostatni, a jednocześnie jeden z nielicznych w jego życiu. Poza Czechami Tomek przebywał w swoim długim życiu właściwie tylko podczas częstych pobytów w Wiedniu (w celu badań naukowych lub jako poseł do parlamentu w 1848 roku i późniejszej Rady Rzeszy) i jego okolicy. Ucieczka przed rewolucją wiedeńską w październiku 1848 roku dała mu nieoczekiwaną okazję do podróżowania przez Górną Austrię. Morawy odwiedził w czasie przejazdów oraz w trakcie obrad autriackiego Sejmu Rzeszy w Kromieryżu w latach 1848/1849. O krótkiej wizycie w Krakowie była już mowa. Samą monarchię Tomek opuścił na kilka tygodni tylko w 1850 roku, kiedy Minister Kultury i Nauki Thun zlecił mu zapoznanie się z organizacją uniwersy teckich seminariów historycznych we Wrocławiu, Berlinie, Getyndze i Paryżu. Było to już wszystko, jeśli nie liczyć krótkiej prywatnej wycieczki do Drezna wiosną 1857 roku $^{32}$ i wspomnianych już niemal corocznych jednodniowych wędrówek na Szczeliniec. Tak więc wędrówka przez śląskie góry pozostała jednym z niezatartych przeżyć tego młodego człowieka.

Region przygraniczny, z którym tak szybko i na trwałe się związał od lat trzydziestych, przedstawiał dla niego krajobraz górski par excellence. Nowe doświadczenie zaczęło wkrótce oddziaływać na sposób, w jaki postrzegał dotąd „normalny” dla siebie krajobraz rodzimych okolic. Tendencja była przy tym nega-

32 W.W. Tomek, Paměti..., t. 1, s. 422. 
tywna. Mianowicie już kiedy w czasie swego pierwszego pobytu latem 1835 roku opuścił okolicę na kilka krótkich dni i znalazł się na wschodnioczeskiej równinie pod Náchodem, odebrał to jako przejście z idylli w mdłą nudę, której brakowało nawet kolorów:

Dzień był piękny; niebo bezchmurne, słońce świeciło; tak jechaliśmy do Bezděkova, a potem w tę przepiękną dolinę, którą widziałem po raz pierwszy w czasie mojej pierwszej podróży do Policy; podróż była wesoła, gdyż w tej okolicy w niedzielę spotyka się szczególnie dużo piechurów; kiedy pozostawiliśmy za sobą Hronov, dotarliśmy na miejsce, w którym dolina Metuji rozszerza się w kierunku Náchodu; dalej po lewej rozciągał się piękny widok na olbrzymią górę oświetloną na niebiesko, potem na lewo Góra Machowska w całej swej urodzie, zielone łąki nad Metują, pasące się na nich bydło, regularnie posadzone drzewa, wijąca się rzeka, wesołe chaty długiej wsi Poříćí, wszystko to bardzo wzruszające. Do pięknego Náchodu dotarliśmy o dziewiątej [...]. Za Náchodem droga prowadzi przez pobliską wieś Stare Miasto, stąd zaś aż do szosy na wysoką górę, a gdy się już przybędzie na górę, kończy się ona nagle i wszędzie rozciąga się równina. To kazało nam się zastanowić, na ile słuszne jest nazywać Náchod górskim przedmieściem, bo gdy tylko wstąpi się $\mathrm{w}$ jego dolinę, jest się zaraz w górach. Przy pierwszym spojrzeniu na szeroką równinę z dalekimi wioskami, dworami i wieżami kościelnymi mało się radowałem, wszystko wydawało mi się zakurzone, taka równina to upokorzenie w porównaniu $\mathrm{z}$ bogatymi kolorami gór ${ }^{33}$.

W ten sposób i tu potwierdza się dialektyka i ambiwalencja stereotypów dyskurs o górach jest zawsze częścią „dyskursu o nizinach” i włącza się w pojmowanie nizin - i vice versa.

\section{Zjęzyka niemieckiego przełożyła} Monika Witt

33 „[D]en byl něco krásný; na nebi wybráno, slunce swjtilo; tak gsme geli k Bezděkowu, a odtud do onného překrásného udolj, gež gsem př̌ mém do Polic cestowání po prwe zpatřil; cesta weselá, neb lidu w této kragině w neděli obzwláště mnoho chodj; Hronow za sebau nechawše, přišli gsme tam kde Metawino udolj se šjřj k Náchodu, za nimž, i od něhož w lewo přewelká hora w modrosti i tak bližšj přeutěšený pohled dáwali, w lewo hora Machowská w celé kráse, luka na Metawě zelená, na nichž dobytek pasaucý-se, stromowe rozsazené, krautjcy-se řeka, aniž méně weselé chalaupky dlauhé wsi Pořiče, to wšecko nemálo pogjmá. Do krásného Náchoda gsme přigeli w 9 hodin [...]. [Za Náchodem] Wede tu cesta přes newelmi wdálenou wjsku »Staré město«, odkudž pak do hori wysoké dělaná sylnice, na niž když se přigede, hora gak by ut’al přsstanau, a rozstjragj se šjroko daleko planiny. Powzbudilo nás toto k rozgjmanj, gak dobrým práwem Náchod hornj předměstj gmenugj, neb sotwa se do geho udolj wstaupj, giž gest w horách. Při prwnjm wzhledu na roztáhlau rowinu s wzdálenými wesmi dwori, i kostelnjmi wěžji, málo gsem se z toho potěšil, wšecko se mě zdálo, gako zaprášené, tak zahanbená planina od hor co do žiwostj barew" - ANM, Spuścizna V.V. Tomka, karton 19, wpis z 20 września 1835. 